\title{
EFFECT OF FAMILIAL MEDITERRANEAN FEVER ON IVF OUTCOME: A RETROSPECTIVE CASE SERIES
}

\author{
Nafiye Karakas Yilmaz ${ }^{1}$, Mustafa Kara ${ }^{2}$, Metin Kaba ${ }^{3}$, Bugra Coskun ${ }^{1}$, \\ Selcuk Erkilinc ${ }^{1}$ and Salim Erkaya ${ }^{1}$
}

\author{
${ }^{1}$ Zekai Tahir Burak Women's Health Education and Research Hospital, Ankara; \\ ${ }^{2}$ Bozok University Medical Faculty, Department of Obstetrics and Gynecology, Yozgat; \\ ${ }^{3}$ Akdeniz University Medical Faculty, Department of Obstetrics and Gynecology, Antalya, Turkey
}

SUMMARY - Although the in vitro fertilization-intra-cytoplasmic sperm injection (IVF-ICSI) has been utilized widely, the management in patients with an autoimmune disease is still a challenge. The aim of this study was to demonstrate IVF-ICSI outcomes in infertile women with familial Mediterranean fever (FMF). Patient data were collected from the cases registered from January 2006 until January 2014. A total of 6152 assisted reproductive technology (ART) cycles were analyzed retrospectively in the Ankara Zekai Tahir Burak Women's Health Education and Research Hospital. Ten infertile women with FMF were included in the study. Baseline clinical and laboratory characteristics were collected and perinatal outcomes evaluated. The mean age (years), duration of infertility (years) and body mass index $\left(\mathrm{kg} / \mathrm{m}^{2}\right)$ were $29.9 \pm 5.3,5.7 \pm 5.3$ and $27.9 \pm 5.7$, respectively. The mean baseline follicle-stimulating hormone (FSH; IU/L), estradiol (E2; pg/mL) and antral follicle count were $7.0 \pm 2.4,48.1 \pm 15.8$ and $7.9 \pm 2.9$, respectively. The distribution of ovarian response was heterogeneous. Fourteen cycles in ten patients were evaluated. Embryo transfer could be achieved in only ten cycles. Three out of ten patients became pregnant. No adverse perinatal outcome was observed. Our findings indicate that FMF might have no impact on ART cycles.

Key words: Familial Mediterranean fever; Infertility; Fertilization, in vitro; Sperm injections, intracytoplasmic; Pregnancy

\section{Introduction}

Although the in vitro fertilization-intra-cytoplasmic sperm injection (IVF-ICSI) has been utilized widely, the management in patients with an autoimmune disease is still a challenge. Numerous mechanisms could lead to infertility such as premature ovarian failure, harmful effects of antibodies on implantation and fertilization, autoimmune oophoritis, etc. Also, antibodies may lead to placental damage, immune rejection, and recurrent pregnancy failure ${ }^{1,2}$.

Familial Mediterranean fever (FMF) is an autosomal recessive disorder characterized by recurrent fever

Correspondence to: Mustafa Kara, MD, Bozok University Medical Faculty, Adnan Menderes Boulevard No. 44, 66200 Yozgat, Turkey E-mail: mustafa.kara@bozok.edu.tr; opdrmustafakara@hotmail.com Received April 14, 2015, accepted November 19, 2015 attacks and abdominal pain. It affects mainly Jewish, Armenian, and Turkish people. In these populations, the incidence of the disease has been documented as being $1 / 500-1 / 1000^{3}$. In accordance with the incidence of FMF in Turkish population, the 10 women cohort was accepted as normal. FMF occurs due to a mutation in the Mediterranean fever (MEFV) gene. The pyrin protein which is expressed by MEFV gene leads to a decrease in the inflammatory mediator levels. Therefore, an abnormality of the gene can lead to an increase in inflammatory response $e^{4-7}$.

The IVF-ICSI has been utilized all over the world for more than three decades now. However, the management of IVF-ICSI in FMF patients remains a challenge for clinicians. Although there are many published studies about the influence of FMF on infertility, the association between FMF and IVF-ICSI out- 
come is still controversial ${ }^{7}$. The relationship between infertility and FMF was first introduced by Ismajovitch et al. ${ }^{8}$. They claimed that FMF could cause infertility due to ovulatory dysfunction in up to $87 \%$ of cases. Dor et al. report that oligomenorrhea was more common in FMF group than in the general population $\left(46 \%\right.$ vs. 31\%) ${ }^{9}$. Unfortunately, the reason for oligomenorrhea is not known. In the same study, interestingly, the pelvic adhesion rate was found to be similar in FMF and control groups, i.e. $31 \%$ and $28 \%$, respectively ${ }^{9}$. Yasar et al. report on retrospective evaluation of 46 pregnant women with FMF, claiming that FMF increased the premature rupture of membranes $(\mathrm{PROM})$, recurrent miscarriages, and preterm delivery rates $^{10}$.

The mechanisms of infertility and impact on perinatal outcome due to FMF remains unclear ${ }^{11}$. Therefore, we aimed to assess whether there is influence of FMF on IVF outcome.

\section{Material and Methods}

\section{Study design}

The aim of this retrospective cohort study was to analyze our assisted reproductive technology (ART) cycle results in FMF patients. The study protocol was approved and ethical consent granted by the local Ethics Committee. Patient data were collected from the cases registered from January 2006 until January 2014. A total of 6152 women admitted to our IVF unit were evaluated. Ten infertile FMF women having undergone 14 ART cycles were included in the study.

The diagnosis of FMF was made by an internal specialist according to clinical symptoms such as intermittent fever, recurrent abdominal pain, family history, and the complaints subsiding with colchicine treatment. All study women were receiving colchicine. Colchicine (Colchicum dispert ${ }^{\circledR}, 0.5 \mathrm{mg}$ tbl, Recordati, Turkey) was administered at a dose of $0.5 \mathrm{mg}$ b.i.d. to suppress FMF attacks.

\section{Gonadotropin stimulation for ART, oocyte retrieval and sample collection}

Agonist and antagonist protocols were used for controlled ovarian hyperstimulation $(\mathrm{COH})$ individually. Flexible daily gonadotropin releasing hormone $(\mathrm{GnRH})$ antagonist protocol was preferred to induce pituitary down-regulation (Cetrotide $0.25 \mathrm{mcg}$, Serono, Switzerland). A dose of 150-225 U daily rec-FSH (Gonal-F, Serono, Istanbul) and/or human menopausal gonadotropin (HMG) (Menogon, Ferring, Switzerland) were started on day 3 of the cycle and continued for the first 3 days of stimulation, after which daily dosing was determined individually. The $\mathrm{GnRH}$ antagonist was started when the leading follicle reached a diameter of 12-14 mm. Serial estradiol (E2) levels and two-dimensional follicle measurements by transvaginal ultrasound imaging (LOGIC 200 PRO, General Electric, Korea) were performed until at least two dominant follicles reached $18 \mathrm{~mm}$ or greater in diameter. Human chorionic gonadotropin (Pregnyl, 10,000 U, im, Organon, The Netherlands) was administered, followed by transvaginal oocyte retrieval $36 \mathrm{~h}$ later. ICSI was performed in all patients according to our clinical practice. Luteal phase support was routinely administered as progesterone in the form of Crinone $8 \%$ gel (Serono, Istanbul), $90 \mathrm{mg}$ daily for 14 days, when a pregnancy test was performed. Clinical pregnancy was diagnosed by ultrasound demonstration of heartbeat in the intrauterine gestational sac. Ongoing pregnancies were followed at our perinatology department. Data on perinatal outcomes were obtained from hospital records.

\section{Statistical analysis}

Statistical analysis was performed using the SPSS 15.00 (SPSS Inc., Chicago, IL, USA). Descriptive analysis was performed.

\section{Results}

Ten patients were included in the study. One and two cycles were performed in 6 and 4 women, respectively. The mean age (years), duration of infertility (years) and body mass index $\left(\mathrm{kg} / \mathrm{m}^{2}\right)$ were $29.9 \pm 5.3$, $5.7 \pm 5.3$ and $27.9 \pm 5.7$, respectively. The mean baseline follicle stimulating hormone (FSH; IU/L), E2 (pg/ $\mathrm{mL}$ ) and antral follicle count were $7.0 \pm 2.4,48.1 \pm 15.8$ and $7.9 \pm 2.9$, respectively. Demographic and clinical characteristics of study patients are shown in Table 1.

Age, baseline FSH and E2 levels, total gonadotropin dose, peak E2 level, endometrial thickness, retrieved oocytes, metaphase II (M II) oocytes, 2 pronucleus (2 PN), transferred embryo number, and clini- 
cal pregnancy rate for each patient are shown in Table 2. The causes of infertility were male factor in $4(40 \%)$, unexplained in $3(30 \%)$, poor ovarian reserve in 2 $(20 \%)$ cases, and tubal factor in $1(10 \%)$ case. The distribution of ovarian response was heterogeneous. Endometrial thickness was found to be within the normal range. Fertilization failure occurred in two patients without male factor. Embryo transfer could be achieved in only ten cycles. Preimplantation genetic diagnosis was not performed because of the patients' choice.

Table 1. Patient characteristics

\begin{tabular}{|l|c|c|}
\hline & Patients $(\mathrm{n}=10)$ & $\mathrm{p}$ value \\
\hline Age (yrs) & $29.9 \pm 5.3$ & NA \\
Duration of infertility (yrs) & $5.7 \pm 5.3$ & NA \\
Baseline FSH (IU/L) & $7.0 \pm 2.4$ & NA \\
Baseline LH (IU/L) & $6.2 \pm 2.0$ & NA \\
Baseline E2 (pg/mL) & $48.1 \pm 15.8$ & NA \\
AFC $(\mathrm{number})$ & $7.9 \pm 2.9$ & NA \\
BMI $\left(\mathrm{kg} / \mathrm{m}^{2}\right)$ & $27.9 \pm 5.7$ & NA \\
\hline
\end{tabular}

$\mathrm{FSH}$ = follicle-stimulating hormone; $\mathrm{LH}=$ luteinizing hormone; $\mathrm{E} 2$ = estradiol; $\mathrm{AFC}=$ antral follicle count; $\mathrm{BMI}=$ body mass index; NA = not applicable
Clinical pregnancy occurred in three women. All these pregnancies were followed at perinatology department. There were no problems throughout pregnancy and newborns were healthy. The mode of delivery was cesarean section in all three women. The birth weight of the babies was $3020 \mathrm{~g}, 2400 \mathrm{~g}$ and $3550 \mathrm{~g}$.

\section{Discussion}

In this study, records of ten infertile women with FMF admitted to the IVF unit of Ankara Zekai Tahir Burak Women's Health Education and Research Hospital were reviewed retrospectively. Three of ten patients became pregnant. As mentioned above, a total of 6152 women were admitted to our IVF unit and 10 FMF cases were detected. These ratios were consistent with the literature.

Familial Mediterranean fever is a chronic disease and the relationship between FMF and infertility is not clear. Various mechanisms could contribute to infertility in patients with FMF. Oligomenorrhea and pelvic adhesions (due to recurrent peritoneal inflammation) are the main causes of infertility in $\mathrm{FMF}^{8,9}$. Colchicine has been utilized for the treatment of FMF since 1974. Colchicine reduces infertility rates as a re-

Table 2. Baseline values and IVF-ICSI outcomes in patients with familial Mediterranean fever

\begin{tabular}{|l|c|c|c|c|c|c|c|c|c|c|c|c|}
\hline Patient & \multirow{2}{*}{$\begin{array}{c}\text { Age } \\
\text { No. }\end{array}$} & \multicolumn{2}{|c|}{ Baseline } & \multirow{2}{*}{ AFC } & $\begin{array}{c}\text { Total gnd. } \\
\text { dose (IU) }\end{array}$ & $\begin{array}{c}\text { End. thick. } \\
(\mathrm{mm})\end{array}$ & $\begin{array}{c}\text { Peak } \\
\text { ES2 }\end{array}$ & ON & M II & 2 PN & TEN & $\begin{array}{c}\text { Clin. } \\
\text { pregn. }\end{array}$ \\
\hline 1 & 24 & 6.6 & 32 & 10 & 2000 & 12 & 4370 & 14 & 10 & 3 & 1 & $(-)$ \\
$1^{\text {a }}$ & 25 & 5 & 64 & 15 & 1625 & 12 & 2220 & 1 & 1 & 0 & 0 & $(-)$ \\
2 & 36 & 5.5 & 30 & 5 & 2925 & 9 & 1408 & 8 & 4 & 3 & 2 & $(-)$ \\
3 & 35 & 8.8 & 49 & 5 & 4950 & 13 & 782 & 2 & 2 & 0 & 0 & $(-)$ \\
4 & 31 & 10.6 & 52 & 10 & 4500 & 11 & 1038 & 2 & 3 & 1 & 1 & $(-)$ \\
5 & 23 & 9 & 79 & 6 & 2250 & 9 & 3587 & 12 & 12 & 7 & 1 & $(+)$ \\
6 & 28 & 5 & 44 & 14 & 1150 & 9 & 3049 & 17 & 12 & 8 & 1 & $(-)$ \\
$6^{a}$ & 30 & 7 & 35 & 9 & 1100 & 7 & 2339 & 17 & 6 & 5 & 1 & $(+)$ \\
7 & 31 & 6.5 & 59 & 13 & 1687 & 12 & 2088 & 8 & 7 & 3 & 1 & $(+)$ \\
8 & 31 & 7.5 & 28 & 15 & 1650 & 10 & 2766 & 21 & 17 & 9 & 1 & $(-)$ \\
9 & 24 & 2.3 & 43 & 19 & 1520 & 8 & 1650 & 11 & 6 & 4 & 1 & $(-)$ \\
$9^{a}$ & 25 & 7 & 47 & 9 & 1400 & 7 & 1530 & 12 & 10 & 8 & 1 & $(-)$ \\
10 & 38 & 10.6 & 62 & 5 & 4500 & 8.5 & 985 & 1 & 1 & 0 & 0 & $(-)$ \\
$10^{a}$ & 38 & 7 & 50 & 5 & 300 & 7.5 & 365 & 4 & 1 & 1 & 0 & $(-)$ \\
\hline
\end{tabular}

IVF-ICSI = in vitro fertilization-intra-cytoplasmic sperm injection; FSH = follicle-stimulating hormone; E2 = estradiol; AFC = antral follicle count; $\mathrm{ON}=$ oocyte count; $\mathrm{M}$ II = metaphase II oocyte; Total gnd. dose = total gonadotropin dose; $2 \mathrm{PN}=2$ pronucleus; End. thick. = endometrial thickness; TEN $=$ transferred embryo number; Clin. pregn. $=$ clinical pregnancy; ${ }^{\mathrm{X}} \mathrm{IU} / \mathrm{L} ;{ }^{\mathrm{Y}} \mathrm{pg} / \mathrm{mL} ;{ }^{\mathrm{a}}$ second cycle 
sult of cessation of FMF attacks. However, this drug could deteriorate sperm functions and numerical anomalies such as oligospermia and azoospermia. But, these side effects are rarely seen ${ }^{11,12}$.

Ehrenfeld et al. ${ }^{13}$ investigated fertility and obstetric history of 36 women with FMF. All the patients were also receiving colchicine treatment. Thirteen (36\%) women had infertility. The causes of infertility were ovulatory dysfunction in 6 (46\%), peritoneal adhesion in 4 (31\%) and unexplained in $3(23 \%)$ cases. However, the limitation of that study was absence of serum hormone levels such as FSH, luteinizing hormone and $\mathrm{E} 2^{13}$. In our study, serum hormone levels were determined and three patients had oligomenorrhea. There are conflicting data about FMF and its influence on infertility. Mamou et al. ${ }^{14}$ report that FMF could lead to ovarian insufficiency. In the present study, poor ovarian response was observed in three patients. On the contrary, Zayed et al. ${ }^{15}$ found that the causes of infertility in FMF were the same as in the general population.

In the light of these data, there is still debate on this issue. Unfortunately, the drawbacks of these studies were small sample sizes and heterogeneity of the populations.

In conclusion, our results indicated that baseline clinical and laboratory characteristics were variable as in the general infertile population. FMF could cause infertility via different mechanisms. In the present study, although the spectrum of the ovarian reserves was variable, we detected similar live birth rates as previously reported. Our study showed that FMF might have no negative impact on ART cycles.

\section{References}

1. Cervera R, Balasch J. Bidirectional effects on autoimmunity and reproduction. Hum Reprod Update. 2008;14:359-66.
2. Bellver J, Pellicer A. Ovarian stimulation for ovulation induction and in vitro fertilization in patients with systemic lupus erythematosus and antiphospholipid syndrome. Fertil Steril. 2009;92:1803-10.

3. Ben-Chetrit E, Levy M. Familial Mediterranean fever. Lancet. 1998;351:659-64.

4. Mijatovic V, Hompes PG, Wouters MG. Familial Mediterranean fever and its implications for fertility and pregnancy. Eur J Obstet Gynecol Reprod Biol. 2003;108:171-6.

5. Kastner DL. Familial Mediterranean fever: the genetics of inflammation. Hosp Pract.1998;15:131-4.

6. Garcia-Gonzalez A, Weisman MH. The arthritis of familial Mediterranean fever. Semin Arthritis Rheum. 1992;22:139-50.

7. Rogers DB, Shohat M, Petersen GM, Bickal J, Congleton J, Schwabe AD, et al. Familial Mediterranean fever in Armenians: autosomal recessive inheritance with high gene frequency. Am J Med Genet.1989;34:168-72.

8. Ismajovich B, Zemer D, Revach M, Serr DM, Sohar E. The causes of infertility in females with familial Mediterranean fever. Fertil Steril. 1973;24:844-7.

9. Dor J, Homburg R, Rabau E. An evaluation of etiologic factors and therapies in 665 infertile couples. Fertil Steril. 1977;28: 718-22.

10. Yasar O, Iskender C, Kaymak O, Taflan Yaman S, Uygur D, Danisman N. Retrospective evaluation of pregnancy outcomes in women with familial Mediterranean fever. J Matern Fetal Neonatal Med. 2014;27:733-6.

11. Forges T, Monnier-Barbarino P, Faure GC, Bene MC. Autoimmunity and antigenic targets in ovarian pathology. Hum Reprod Update. 2004;10:163-75.

12. Ben-Chetrit E, Levy M. Reproductive system in familial Mediterranean fever: an overview. Ann Rheum Dis. 2003;62:916-9.

13. Ehrenfeld M, Brzezinski A, Levy M, Eliakim M. Fertility and obstetric history in patients with familial Mediterranean fever on long-term colchicine therapy. Br J Obstet Gynaecol. 1987; 94:1186-91.

14. Mamou H. Maladie periodique et troubles endocriniene. Semin Hop. 1970;46:2027-9. (in French)

15. Zayed A, Nabil H, State O, Badawy A. Subfertility in women with familial Mediterranean fever. J Obstet Gynaecol Res. 2012;38:1240-4. 


\section{Sažetak}

\section{UTJECAJ OBITELJSKE MEDITERANSKE VRUĆICE NA ISHOD IZVANTJELESNE OPLODNJE: RETROSPEKTIVNA ANALIZA NIZA SLUČAJEVA}

\section{N. Karakas Yilmaz, M. Kara, M. Kaba, B. Coskun, S. Erkilinc i S. Erkaya}

Iako je metoda oplodnje in vitro i intracitoplazmatskog injektiranja sperme (in vitro fertilization-intra-cytoplasmic sperm injection, IVF-ICSI) danas široko rasprostranjena u čitavom svijetu, njezina primjena u bolesnica s autoimunim bolestima još uvijek predstavlja velik izazov. Cilj ovoga istraživanja bio je pokazati ishode IVF-ICSI kod neplodnih žena s obiteljskom mediteranskom groznicom (familial Mediterranean fever, FMF). Podaci bolesnica prikupljeni su iz registriranih slučajeva od siječnja 2006. do siječnja 2014. godine. Retrospektivna analiza provedena u Zekai Tahir Burak Women’s Health Education and Research Hospital u Ankari obuhvatila je 6152 ciklusa potpomognute oplodnje (assisted reproductive technology, ART). U istraživanje je bilo uključeno deset neplodnih žena s FMF. Uzeti su bazalni podaci o kliničkim i laboratorijskim značajkama uključenih žena, kao i perinatalnim ishodima. Srednje vrijednosti dobi (godine), trajanja neplodnosti (godine) i indeksa tjelesne mase $\left(\mathrm{kg} / \mathrm{m}^{2}\right)$ bile su 29,9 $\pm 5,3 ; 5,7 \pm 5,3$ odnosno $27,9 \pm 5,7$. Srednje vrijednosti folikul-stimulirajućeg hormona (FSH;

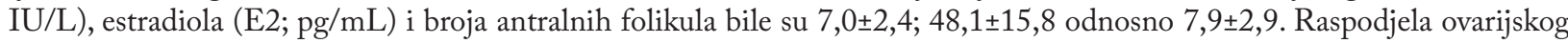
odgovora bila je heterogena. Procijenjeno je 14 ciklusa u deset žena. Transfer embrija bio je moguć u samo deset ciklusa, a trudnoća je postignuta u tri od deset žena. Nije zabilježen nikakav štetni perinatalni ishod. Naši nalazi ukazuju na to da FMF možda nema nikakvog utjecaja na cikluse ART.

Ključne riječi: Obiteljska mediteranska vrućica; Neplodnost; Fertilizacija, in vitro; Sperma, intracitoplazmatske injekcije; Trudnoća 